\title{
PENGARUH PERSEPSI TERHADAP KEPUTUSAN PEMBIAYAAN MELALUI KESADARAN MEREK
}

\author{
Sarwoto \\ Program Strata I Manajemen STIE Bina Karya Tebing Tinggi, Sumatra Utara \\ sarwotohisyam@gmail.com \\ Sri Winda Hardiyanti Damanik \\ Program Strata I Manajemen STIE Bina Karya Tebing Tinggi, Sumatra Utara \\ sriwindahardiyantid@gmail.com
}

\begin{abstract}
Abstrak Penelitian dilakukan pada 120 responden sebagai nasabah UMKM PT Bank Syariah Indonesia. Responden adalah nasabah yang memiliki pembiayaan pada PT BSI di cabang kabupaten Batu Bara. Produk pembiayaan dimaksud berupa pembiayaan mikro dengan kolektibilitas lancar. Sampling dengan metode accidental sampling. Model penelitian dengan SEM, pengolahan data dengan soft ware smart PLS 3.0. Hasil penelitian menjawab tujuan penelitian yaitu persepsi berpengaruh terhadap keputusan pembiayaan, kesadaran merek berpengaruh terhadap keputusan pembiayaan dan kesadaran merek tidak menjadi variabel moderating dalam pengaruh persepsi kualitas terhadap keputusan pembiayaan.

Kata Kunci Nasabah,Persepsi, merek, keputusan dan pembiayaan
\end{abstract}

\section{PENDAHULUAN}

Usaha mikro kecil menengah (UMKM) merupakan sektor usaha yang paling banyak menggerakan ekonomi bangsa Indonesia. Sesuai rilis oleh Bank Indonesia pada tahun 2019 di provinsi Sumatra Utara jumlah UMKM berkisar 2.800.000 unit usaha atau sebesar 4,75\% dari total UMKM secara nasional, Dari 2.800.000 unit UMKM ini berkisar 33.678 unit ada di Kabupaten Batu Bara(B. P. S.- SUMUT, 2020). UMKM menjadi pilihan yang paling mudah untuk dimasuki sebab tidak membutuhkan modal uang yang besar namun cukup dengan memanfaatkan kemampuan yang dimiliki dan memanfaatkan matrial yang dimiliki disekitar tempat tinggal(Harahap et al., 2020). Mudahnya UMKM dimasuki sebaliknya mudah juga orang meninggalkan atau keluar dari sektor UMKM(Sarwoto, 2018). Usaha UMKM rentan terhadap perubahan kondisi ekonomi terutama perubahan harga-harga bahan baku untuk UMKM produsen atau harga pembelian persediaan barang untuk UMKM jasa pedagang perantara.

Perubahan kondisi ekonomi mengakibatkan perubahan kebutuhan modal kerja sehingga perubahan ini direspon oleh pelaku UMKM dengan menambah modal kerja. Penambahan modal kerja salah satunya bersumber dari hutang atau pembiayaan kepada pihak ketiga yaitu perbankan. Salah satu perbankan yang melayani pembiayaan adalah PT Bank Syariah Indonesia. PT BSI merupakan penggabungan dari tiga bank syariah yang miliki oleh bank pemerintah yaitu PT BSM, PT BRI Syariah dan BNI Syariah. Penggabungan tiga bank syariah menjadi PT BSI mampu mengangkat posisi bank syariah 
masuk menjadi 10 bank besar di Indonesia. Begitupun portofolio pembiayaan mikro PT BSI menjadi lebih besar dan berkesempatan meningkatkan pembiayaan sektor UMKM.

Kabupaten Batu Bara menjadi salah satu sasaran pengembangan pembiayaan mikro PT BSI dengan memanfaatkan kantor cabang yang sebelumnya kantor cabang PT BSM, PT BSI meningkatkan pembiayaan mikronya di kabupaten Batu Bara. Banyaknya UMKM di kabupaten Batu Bara merupakan potensi yang sangat besar guna peningkatan portofolio pembiayaan mikro PT BSI. PT BSI dengan modal yang besar tidak saja besar sebab keuangan namun dikelola oleh insan-insan yang memiliki pengalaman dalam mengelola perbankan.

Kemampuan PT BSI menimbulkan keyakinan kepada nasabahnya untuk menggunakan jasa PT BSI, termasuk memilih PT BSI untuk memberikan pembiayaan kepadanya. Keputusan memilih pembiayaan mikro PT BSI juga dapat dipengaruhi oleh indentitas syariah yang melekat pada nama perusahaan. Persepsi ajaran Islam mempengaruhi persepsi terhadap produk yang menggunakan indentitas atau kata atau symbol yang berkorelasi dengan Islam seperti kata syariah. Persepsi kata syariah itu Islam mempengaruhi keputusan terhadap pemilihan perbankan syariah(Masit, 2016). Hal ini didukung juga penelitian oleh cahyani (Cahyani et al., 2013).

Kabupaten Batu Bara berpenduduk mayoritas Islam tentunya tidak asing dengan kata-kata syariah sebab syariah memiliki konotasi dengan ke Islaman. Islam sebagai agama yang diyakini dapat membawa pengikutnya pada keyakinan kebenaran ajaran yang berkaitan dengan ekonomi berdasar ajaran Islam. Sadar Islam sebagai panduan dalam hidup, umat Islam juga menyadari perlunya memutuskan atau memilih produk yang menunjukan keislamannya. Kesadaran menggunakan produk yang Islami mendorong nasabah UMKM memilih merek yang Islami. Kesadaran penggunaan merek yang Islami didukung dalam penelitian sebelumnya oleh (Hidayah \& Prabawani, 2016).

\section{LANDASAN TEORI}

\section{Keputusan pembiayaan}

Keputusan pembiayaan dapat juga diartikan keputusan pembelian, keputusan pembelian adalah memutuskan untuk memilih salah satu dari beberapa alternative yang ada, sebelumnya alternative dikumpulkan dari banyaknya informasi yang tersedia dipasar baik yang sengaja di cari ataupun yang terkumpul dari ketidak sengajaan(Kotler, 2009). Disaat konsumen mencari iformasi produk yang akan di beli menjadi titik kritis bagi perusahaan untuk mengenalkan produknya dengan sengaja. Kesengajaan perusahaan mengenalkan produknya melalui merek yang mudah di ingat dan memiliki nilai sendiri, terutama nilai yang menyentuh sisi emosional konsumen.

Untuk memenuhi maksud keputusan pembelian konsumen memutuskan memilih pembiayaan dengan memilih produk atau jasa yang sesuai kebutuhan, memilih merek yang dapat memenuhi kebutuhan, memilih penyalur atau produsen yang dapat memenuhi kebutuhan, memilih kuantitas atau jumlah tertentu untuk memenuhi kebutuhannya, memilih waktu yang tepat untuk melakukan pembelian dan memilih metode pembayaran(Kotler, 2009). Keputusan pembelian bisa dengan mempertimbangkan halhal yang dianggap baik dari sebuah produk sehingga menutupi hal-hal yang dianggap buruk dari sebuah produk(Zainal, 2017).

\section{Persepsi}

Persepsi adalah proses yang digunakan oleh individu untuk memilih, mengorganisasi dan menginterpretasikan masukan informasi guna menciptakan 
gambaran merek yang memiliki arti(Kotler, 2009). Banyaknya penawaran yang dilakukan perusahaan dalam satu situasi yang didukung oleh lingkungan yang mampu membuat suasana hati konsumen akan membentuk persepsi pada situasi tersebut sehingga konsumen memiliki persepsi yang baik dan terpengaruh untuk membeli pada saat bersamaan. Dalam pemasaran persepsi lebih penting dari realitas sebab persepsi mempengaruhi tindakan aktual konsumen(Kotler, 2009). Proses persepsi terdiri dari perhatian selektif, distorsi selektif, ingatan selektif dan persepsi subliminal(Kotler, 2009).

\section{Kesadaran Merek}

Merek diartikan sebagai nama, istilah, tanda, lambang, atau desain, atau kombinasinya yang dimaksudkan untuk mengidentifikasikan barang atau jasa dari salah satu penjual atau kelompok penjual dan mendiferensiasikan mereka dari para pesaing(Kotler, 2009). Pendeferensisian dari satu merek dengan merek lain bisa bersifat simbolis, emosional atau tidak nyata yang berkaitan dengan apa saja yang merepresentasikan merek tersebut. Diferensiasi merek dapat berupa produk, pelayanan, tenaga kerja dan distribusi atau tempat. Tahapan kesadaran merek terdiri dari unware of brand,brand recognition, brand recall dan top of mind(Zainal, 2017).

\section{METODOLOGI PENELITIAN}

Dalam penelitian ini menggunakan model Structural Equation Model (SEM), Metode pengolahan data menggunakan soft ware Smart PLS 3.0, alfa sebesar 0,05 (5\%) jumlah sampel sebanyak 120 responden sehingga nilai $t_{\text {tabel }}$ sebesar1,980. Pengujian instrument menggunakan uji validitas dari hasil analisa data menggunakan table HTMT dan pengujian realibity instrument menggunakan table AVE. Untuk melihat model struktural akan menggunakan structural model analysis atau inner model dengan melihat hasil analisa pada table R-square. Setelah instrument dinyatakan valid dan reliabel serta model yang diusulkan dinyatakan fit atau baik baru dilakukan pengujian hipotesis berdasar nilai path coefficients(Ghazali, 2014).

\section{HASIL PENELITIAN}

Setelah melakukan pengumpulan data dan pengolahan dengan soft ware hasil penelitian disajikan sebagai berikut:

\section{uji validitas}

Table IV.1 nilai HTMT

\begin{tabular}{|l|r|r|r|r|}
\hline & $\begin{array}{l}\text { Original } \\
\text { Sample } \\
(\mathbf{O})\end{array}$ & $\begin{array}{l}\text { Sample } \\
\text { Mean (M) }\end{array}$ & $\mathbf{2 . 5 \%}$ & $\mathbf{9 7 . 5 \%}$ \\
\hline kesadaran merek -> keputusan pembiayaan & 0.746 & 0.750 & 0.619 & 0.876 \\
\hline persepsi kualitas -> keputusan pembiayaan & 0.883 & 0.881 & 0.796 & 0.948 \\
\hline
\end{tabular}

Tabel IV.1 menunjukan validitas instrument baik sebab nilai masing-masing lebih besar dari 0,7. sehingga memenuhi syarat HTMT sebagai ukuran validitas instrument.

Uji reliabilitas

\begin{tabular}{|l|r|r|r|r|r|}
\hline & \multicolumn{2}{|l}{ Original } \\
& $\begin{array}{l}\text { Sample } \\
\text { (O) }\end{array}$ & $\begin{array}{l}\text { Sample } \\
\text { Mean (M) }\end{array}$ & $\begin{array}{l}\text { Standard } \\
\text { Deviation } \\
\text { (STDEV) }\end{array}$ & $\begin{array}{l}\text { T Statistics } \\
(\mid \text { O/STDEV|) }\end{array}$ & P Values \\
\hline keputusan pembiayaan & 0.912 & 0.911 & 0.019 & 47.079 & 0.000 \\
\hline kesadaran merek & 0.901 & 0.902 & 0.020 & 46.166 & 0.000 \\
\hline
\end{tabular}




\begin{tabular}{|l|l|l|l|l|l|}
\hline persepsi kualitas & 0.900 & 0.900 & 0.018 & 49.936 & 0.000 \\
\hline
\end{tabular}

Tabel IV.2 menunjukan validitas instrument baik sebab nilai masing-masing lebih besar dari 0,7. sehingga memenuhi syarat AVE sebagai ukuran reliabilitas instrument.

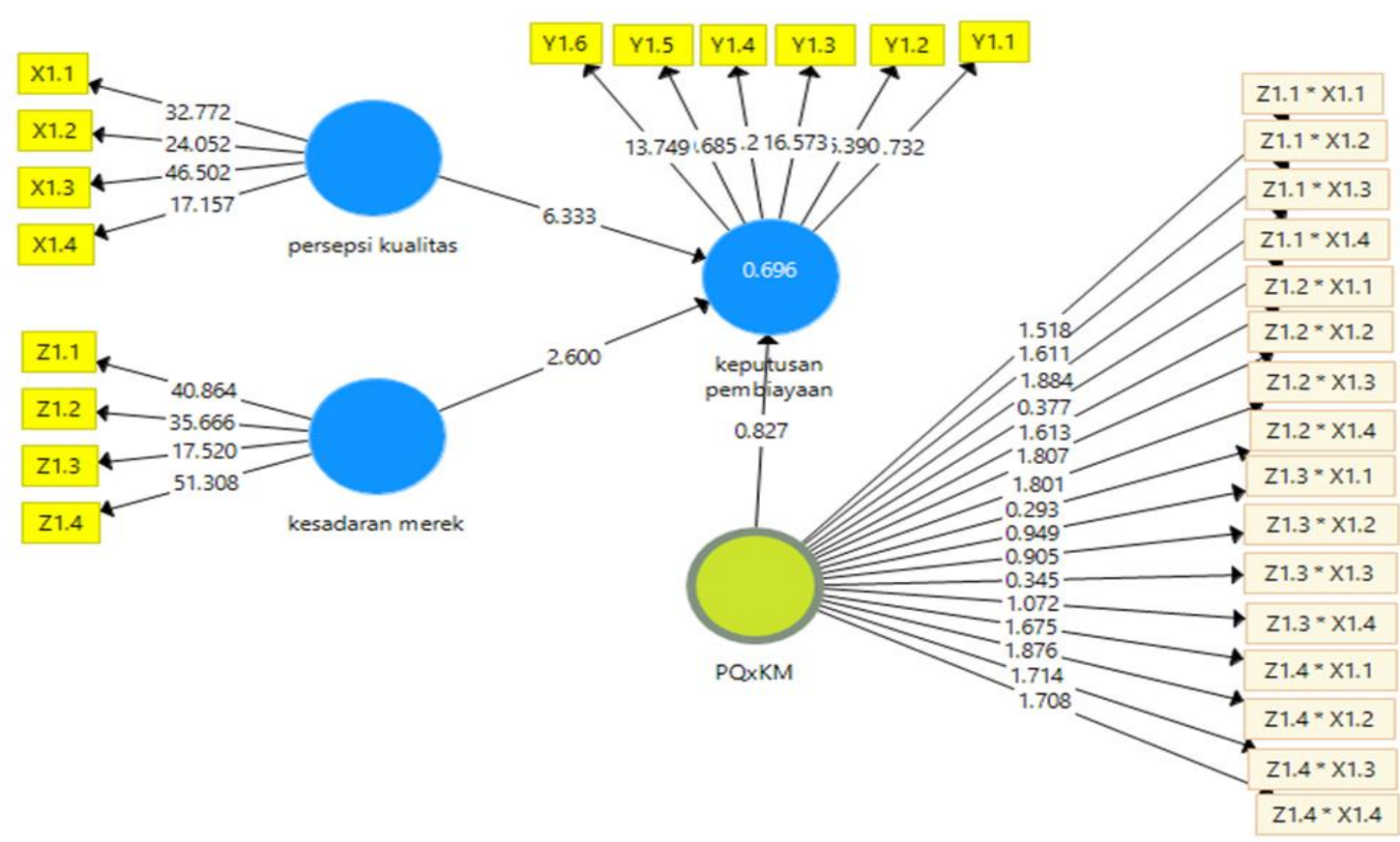

Gambar IV.1 gambar structural model analysis

\section{Structural Model Analysis}

Gambar IV.1 memperlihatkan persepsi kualitas mempengaruhi keputusan pembiayaan hal ini didukung oleh nilai $t_{\text {statistik }}$ lebih besar dari $t_{\text {tabel }}(6,333>1,980)$ sesuai penelitian oleh Prastiwi et.all (Prastiwi, 2018). Berikutnya kesadaran merek berpengaruh terhadap keputusan pembiayaan hal ini didukung oleh nilai $t_{\text {statistik }}$ lebih besar dari $t_{\text {tabel }}$ $(2,600>1,980)$ sesuai penelitian oleh Alifianti et.all (Alifianti Analisa Trisnawat, 2016). Efek moderasi menunjukan nilai $t_{\text {statistik }}$ lebih kecil dari tabel $(0,827<1,980)$ berarti kesadaran merek tidak dapat menjadi variabel moderating.

\section{Koefisien Determinan (R Square)}

Pada gambar IV.1 memperlihatkan besarnya nilai R square sebesar 0.696 atau 69,6\%. Hal ini menjelaskan besarnya kemampuan persepsi kualitas dalam menjelaskan keputusan pembiayaan sebesar $69,6 \%$ sisanya $31,4 \%$ dijelaskan oleh variabel lain yang tidak diteliti dalam penelitian ini.

\section{KESIMPULAN}

Kesimpulan dalam penelitian adalah persepsi nasabah UMKM PT BSI berpengaruh terhadap keputusan pembiayaan. Kesadaran merek berpengaruh terhadap keputusan pembiayaan nasabah UMKM PT BSI. Kesadaran merek tidak menjadi variabel moderating antara persepsi nasabah UMKM PT BSI terhadap keputusan pembiayaan.

\section{UCAPAN TERIMA KASIH}

Kami ucapkan terimakasih atas dukungan dari pihak-pihak yang membantu menyelesaikan penelitian ini, terimakasih kepada STIE Bina Karya Tebing Tinggi, 
pengelola jurnal JESYA, STIE Al-Wasliyah Sibolga, dan pihak-pihak yang tidak kami sebutkan.

\section{DAFTAR PUSTAKA}

Alifianti Analisa Trisnawat. (2016). PENGARUH KESADARAN MEREK, LOYALITAS MEREK, DAN CITRA MEREK TERHADAP KEPUTUSAN PEMBUKAAN REKENING TABUNGAN BRI SIMPEDES DI SURABAY. http://eprints.perbanas.ac.id/2199/1/ARTIKEL ILMIAH.pdf

Cahyani, A. F., Saryadi, \& Nurseto, S. (2013). Pengaruh Persepsi Bunga Bank dan Kualitas Pelayanan Terhadap Minat Menabung. DIPONEGORO JOURNAL OF SOCIAL AND POLITIC Tahun 2013, Hal. 1-8 Http://EjournalS1.Undip.Ac.Id/Index.Php/ Pengaruh, 1-9.

Ghazali, P. H. I. (2014). Structural Equation Modeling Metode alternatif dengan Partial Least Square (4th ed.). Badan Penerbit -UNDIP.

Harahap, I., Nuruddin, A., Batubara, C., Syahnan, M., \& Sukiati, S. (2020). Small and Medium-Sized Enterprises (SMEs), Islamic Bank, and Religiosity. https://doi.org/10.4108/eai.8-10-2018.2288721

Hidayah, L., \& Prabawani, B. (2016). Pengaruh Suku Bunga, Pelayanan Dan Kesadaran Merek (Brand Awareness) Terhadap Keputusan Pengambilan Kpr (Studi Pada Nasabah Pt Bank Tabungan Negara Kantor Cabang Semarang). Jurnal Ilmu Administrasi Bisnis, 5(4), 458-465. https://ejournal3.undip.ac.id/index.php/jiab/article/view/13592

Kotler, P. (2009). Manajemen Pemsaran (M. Adi (ed.); 13th ed.). PT Glora Aksara Pratama.

Masit, T. E. (2016). PENGARUH BRANDING TERHADAP PERILAKU KONSUMEN. 13(1), 40-72.

Prastiwi, I. E. (2018). Pengaruh Persepsi Anggota Pada Sharia Compliance, Komitmen Agama dan Atribut Produk Islam Terhadap Customer's Trust Yang Berdampak Pada Keputusan Menggunakan Jasa Lembaga Keuangan Syariah (Studi Pada BMT Amanah Ummah Sukoharjo). Jurnal Ilmiah Ekonomi Islam, 4(01), 28.

https://doi.org/10.29040/jiei.v4i1.162

Sarwoto. (2018). ANALISIS PENGARUH MOTIVASI UMKM NASABAH PT BSM TERHADAP KEPUTUSAN PEMBIAYAAN MELALUI. INSIS, I(1).

SUMUT, B. P. S.-. (2020). Sumatra Utara Dalam angka 2020 (B. SUMUT (ed.)). BPS SUMUT.

Zainal, V. R. (2017). Islamic Marketing Management (S. Y. N. Indah (ed.); 1st ed.). 